\title{
The Protective Effect of Amino-guanidine, an Inducible Nitric Oxide Synthase Inhibitor, on Aluminium Sulphate Neuro-toxicity in the Rat (Wistar albino) Cerebellar Purkinje Cells: Stereological Study
}

\author{
Hayri Genç ${ }^{1}$, Bengi Baysal ${ }^{1}$, Banu Eren ${ }^{1}$, Burcu Demirel Y1lmaz ${ }^{2}$ \\ ${ }^{1}$ Ondokuz Mayis University Faculty of Arts and Sciences, Samsun, Turkey \\ ${ }^{2}$ Ordu University, Akkuş Vocational School, Akkuş, Ordu, Turkey
}

Received: 16 June 2017, Accepted: 31 August 2017, Published online: 28 December 2017 (C) Ordu University Institute of Health Sciences, Turkey, 2017

\begin{abstract}
Objective: Aluminium (Al) is quite abundant in nature and humans are frequently exposed to $\mathrm{Al}$ in daily life. Aluminium salts can exist in different forms and they may have toxic impacts on several tissues including brain. In this study, potential preventive effects of amino-guanidine (AG) (100 mg/kg, i.p.), an inducible nitric oxide synthase inhibitor, on neuron damage to be created by aluminium sulphate $(3 \mathrm{mg} / \mathrm{kg}$, i.c.v.) in cerebellar Purkinje cells were determined.

Methods: 24 female Wistar albino rats were divided into 4 groups with 6 rats in each: Control (C), Sham (S), Aluminium sulphate $\left(\mathrm{Al}_{2}\left(\mathrm{SO}_{4}\right)_{3}\right)$, Aluminium sulphate + Amino-guanidine $\left(\mathrm{Al}_{2}\left(\mathrm{SO}_{4}\right)_{3}+\mathrm{AG}\right)$. A single aluminium sulphate $(3 \mathrm{mg} / \mathrm{kg})$ dose dissolved in $0.9 \% \mathrm{NaCl}$ was injected intracerebroventricularly to aluminium sulphate and aluminium sulphate + amino-guanidine groups at the beginning of experiments. Following aluminium sulphate injection, amino-guanidine $(100 \mathrm{mg} / \mathrm{kg})$ dissolved in distilled water was injected to aluminium sulphate + amino-guanidine group intraperiteonally for 15 days. Nothing was administered to control group, a single dose of $0.9 \%$ (3 mg/kg, i.c.v.) sodium chloride $(\mathrm{NaCl})$ was administered to sham group at the beginning of experiments. Cerebellum tissues of the rats were removed 15 days after treatments and they were assessed histopathologically and stereologically.

Results: Stereological optic fractionation method revealed cerebellar total number of Purkinje cells as $417615 \pm 16238,8$ in control group; $378650 \pm 20171$,6 in Sham group; $272945 \pm 15499,5$ in Aluminium sulphate group; $324581 \pm 16324,8$ in Aluminium sulphate + Amino-guanidine group.

Conclusion: It was concluded based on present findings that amino-guanidine reduced aluminium induced Purkinje cell loss through nitric oxide synthase (NOS) inhibition.

Key words: Aluminium, Amino-guanidine, Cerebellum, Purkinje cell, Stereology

Address for correspondence/reprints:

Burcu Demirel Y1lmaz

Telephone number: +90 (452) 6112555 / 4905

E-mail: bioburcudemirel@gmail.com

DOI: $10.19127 / \mathrm{mbsjohs} .322015$

\section{Introduction}

Chemical pollutants not only pollute environment, but also they have long-standing impacts on cellular development (Önger et al., 2011). Aluminium ( $\mathrm{Al}$ ) always exists in environment and humans are continuously exposed to aluminium (Yavuz et. al., 2013). It doesn't have a known biological function and it's the third abundant element in nature (Oğuz et al., 2012). Al can be found in broad range of items from drugs to tools, from kitchenware to electric industry, from vehicles
\end{abstract}


to cosmetics (Yavuz et. al., 2013). Al can get into the human body through oral, penetration, inhalation, skin etc. (Yokel et al., 2008). Just because of abundance in nature, it can accumulate in tissues of organisms to certain extend (Oğuz et al., 2008), may have neurotoxic impacts resulting in Alzheimer and Parkinson-like neurological disorders (Kamal and Kamal, 2013).

Clinical studies with animals revealed that brain was a significant target organ in $\mathrm{Al}$ neurotoxicity (Kamal and Kamal, 2013). Al can accumulate in all sections of the brain and may have maximum accumulation in hippocampus. Al accumulation in tissues induces the formation of reactive oxygen species and then these species result in protein, lipid and DNA oxidation. Neural membranes of central nervous system are quite rich in polyunsaturated fatty acids, have low antioxidant enzyme levels and need significant quantities of oxygen for metabolism. Therefore, they are quite more prone to oxidative damage than the other systems. Al has a cytotoxic impact on brain through inhibition of $\mathrm{Ca}_{2}+$ ATPaz responsible for sustaining quite low $\mathrm{Ca}_{2}+$ levels in cells by pumping $\mathrm{Ca}_{2}+$ in brain out of the cells. Increase in neural $\mathrm{Ca}_{2}+$ activates various protease enzymes of caspase family and may result in irreversible neural damage. $\mathrm{Al}$ also increases the quantities of glutamate, an excitatory neurotransmitter existing in about $40 \%$ of synapse in brain. When the $\mathrm{Al}$ around a neuron reached to a certain level, it annihilates the neuron through apoptosis. An uncontrolled increase in glutamate quantity of synaptic gap activates N-methyl Daspartic acid (NMDA), increases $\mathrm{Na}+$ and $\mathrm{Ca}_{2}+$ ion concentrations along the cell membrane and aggravate neurological damage (Çabuş, 2012).

Together with recently increased atmospheric pollution, nitric oxide (NO) is another remarkable compound. NO is known as a basic precursor molecule and called as a free radical molecule because of unpaired electron. While the other free radicals are harmful to cells at any concentrations, NO play a role in quite significant physiological functions at low concentrations. However, excessive and uncontrolled NO synthesis may be harmful for cells (Özgüneş and Atasayar, 2009). In case of excessive production, NO confronts us as a neurotoxin in various nervous system diseases (Satarug et al., 2000). Nitric oxide (NO) is synthesized from L-arginine by nitric oxide synthase (NOS) (Buraimoh et al., 2014). NOS exist in brain tissues of humans and animals at varying concentrations (Türköz and Özerol, 1997). There are three NOS isoforms in brain as of endothelial
(eNOS), neural (nNOS) and inducible (iNOS) (Stevanović et al., 2010). iNOS is an enzyme able to produce NO to a level with toxic effects (Gross and Volin, 1995). Cytokines and stimulant substances induced by acute inflammatory changes may also contribute to iNOS enzyme activation just as in immunological or inflammatory stimulations and may produce toxic NO levels which can be expressed as nanomole throughout subsequent couple days of pathological stimulation and ultimately aggravate the damage which may end up with cell death (Önger et al., 2011).

Amino-guanidine (AG), used to reduce toxic impacts of $\mathrm{Al}$ on Purkinje cells, structurally resembles to L-Arginine amino acid, inhibits iNOS and thus result in reduced NO formation (Budavari et al., 1989). It was reported in a previous study that AG prevented inflammation in hippocampus as a selective iNOS inhibitor and reduced neuron damage (Anaeigoudari, 2016). It was also reported that AG had scavenging activity in various tissue damage models through scavenging hydrogen peroxide $\left(\mathrm{H}_{2} \mathrm{O}_{2}\right)$ derivative hydroxyl radicals $(\mathrm{OH}-)$ produced from $\mathrm{NO}$ and superoxide $\left(\mathrm{O}_{2-}\right)$ (Polat et al., 2006). In this sense, AG prevents lipid peroxidation and formation of reactive oxygen species (ROS) and thus reduces toxicity through the impacts like as an antioxidant agent (Babu et al., 1995).

Cerebellum, over which toxic effects of $\mathrm{Al}$ were investigated, is one the most complex sections of central nervous system of mammalian (Tunç et al., 2007). Nearly $50 \%$ of all neurons of the brain are located in cerebellum, which takes up only $10 \%$ of the total brain volume and receives nearly 200 million afferent fibers (Eweka and Om'Iniabohs, 2007). Cerebellum is responsible for the control of motor movements through comparing information coming to brain from various receptors in periphery with the responds of brain to this information. While performing this function, Purkinje cells are the only output of cerebellum cortex. Therefore, Purkinje cells have a great place in cerebellum functions. These cells are also quite sensitive to alcohol toxicity and ischemia-like pathologic cases (Kozan et al., 2009). High number of NMDA receptors creating neurotoxic effects of $\mathrm{NO}$ in cerebellum also aggravates NOS activity (Sefil et al., 2009). It was reported in previous $\mathrm{Al}$ studies that with increasing NOS levels in brain tissue (Flora et al., 2003), Al created oxidative stress in cortex and cerebellum (Esparza et al., 2005) and had neurotoxicity on cerebellar Purkinje cells (Buraimoh et al., 2014).

Although brain is the primary target organ in $\mathrm{Al}$ toxicity, effects of $\mathrm{Al}$ on cerebellum were 
investigated in limited number of studies. Therefore, the present study was designed to elucidate the preventive effect of amino-guanidine (AG) as a specific nitric oxide synthase (NOS) inhibitor against potential damage of $\mathrm{Al}$ to be created on cerebellum Purkinje cells through stereological optic fractionation method with systematic randomized sampling and unbiased counting.

\section{Methods}

\section{Experimental Procedure}

Experiments were conducted with Wistar albino rats grown in Laboratory Animals Implementation and Research Center of Ondokuz Mayıs University. About $200 \pm 250 \mathrm{~g} 24$ same-generation rats were selected and they were randomly divided into four groups with 6 rats in each. These groups were control (C), Sham (S), Aluminium sulphate $\left(\mathrm{Al}_{2}\left(\mathrm{SO}_{4}\right)_{3}\right)$, Aluminium sulphate + Amino-guanidine $\left(\mathrm{Al}_{2}\left(\mathrm{SO}_{4}\right)_{3}\right.$ $+\mathrm{AG}$ ). In this study, $3 \mathrm{mg} / \mathrm{kg}$ of aluminum sulphate (Çabuş et al. 2014) and $100 \mathrm{mg} / \mathrm{kg}$ of aminoguanidine (Önger et al., 2011) were applied to experimental groups. Rats were placed in plastic cages at $20 \pm 22^{\circ} \mathrm{C}$ temperature, $50 \%$ relative humidity and 12 hours' light/dark periods. Feed and water was supplied ad libitum.

\section{Chemicals and Method of Administration}

Aluminium sulphate was supplied from SigmaAldrich as aluminium sulphate hydrate (in powder, pure form), Amino-guanidine was supplied from again Sigma-Aldrich as amino-guanidine hydrochloride (in powder, pure form).

Rats were weighted before the injections and they were anesthetized through intraperitoneal ketamine $(100 \mathrm{mg} / \mathrm{kg})$ and xylazine $(10 \mathrm{mg} / \mathrm{kg})$ administration (Sefil et al., 2009). Rats were than fixed to streotaxy device and their scalp was opened $2 \mathrm{~cm}$ with an electrical cautery (Ellman Surgitron) from the midsection along rostro-caudal direction. Tendon and fascia over cranium were removed to see Bregma clearly. As to comply with left lateral ventricle, 1 $\mathrm{mm}$ hole was opened at $2 \mathrm{~mm}$ lateral and $0.6 \mathrm{~mm}$ posterior of Bregma (Kozan et al., 2009). From there, Hamilton micro-injector was introduced and 2 $\mu 1$ aluminium sulphate solution was injected intracerebroventricularly (i.c.v.) to a depth of 4.2 $\mathrm{mm}$ at $0.5 \mu \mathrm{l} / \mathrm{min}$ flow rate and $3 \mathrm{mg} / \mathrm{kg}$ dose. Nothing was administered to control group. A single dose of $0.9 \%$ (3 $\mathrm{mg} / \mathrm{kg}$, i.c.v.) sodium chloride $(\mathrm{NaCl})$ was administered to sham group at the beginning of experiments. A single aluminium sulphate $\left(3 \mathrm{mg} / \mathrm{kg}\right.$, i.c.v. $\left.\mathrm{Al}_{2}\left(\mathrm{SO}_{4}\right)_{3}\right)$ dose dissolved in $0.9 \% \mathrm{NaCl}$ was administered to $\mathrm{Al}_{2}\left(\mathrm{SO}_{4}\right)_{3}$ and
$\mathrm{Al}_{2}\left(\mathrm{SO}_{4}\right)_{3}+\mathrm{AG}$ groups at the beginning of experiments. Amino-guanidine (AG) was injected to $\mathrm{Al}_{2}\left(\mathrm{SO}_{4}\right)_{3}+\mathrm{AG}$ group for 15 days at a dose of 100 $\mathrm{mg} / \mathrm{kg}$, i.p. After 15 days following the last injection, rats were perfused intracardially under ketamine ( 75 $\mathrm{mg} / \mathrm{kg}$, i.p.) and xylazine $(10 \mathrm{mg} / \mathrm{kg}$, i.p.) anesthesia. Rat brains were put into $10 \%$ neural-tamponed formalin solution for stereological examination.

\section{Sampling via Optical Fractionation}

Total number of Purkinje cell in the cerebellum was performed by the optical fractionation method, which is a combination of two stereological applications (fractionation and optical dissector) (Korkmaz et al., 1996; Korkmaz and Tumkaya, 1997; Korkmaz et al., 2000). Systematic random sampling was performed from cerebellum tissue immersed into paraffin in accordance with fractionation principles. The issue to be considered in sampling was to have a proper error coefficient (0.05 or less) and coefficient of variation (0.10). The calculation results below these two values prove the accuracy of the sampling process (Gundersen and Jensen, 1987). Present samplings were performed by considering proper error coefficients and coefficients of variation. In this direction, cerebellum tissues of the all group rats were sectioned from back to front at $30 \mu \mathrm{m}$ intervals, leaving no tissue unused. Section sampling fraction in systematic random sampling was determined as (f1) $1 / 7$ and the first cross-section based on randomness principle was taken randomly from the 1-4th sections, the other cross-sections were taken from the 7th section through by passing 6th section over the initially selected section. In this way, about 25-28 cerebellum sections were obtained from each rat. The selected sections after sampling were stained with cresyl violet. For section sampling fraction (F2), the approach in West et al., (1991) was tried to be applied. F2 was calculated by dividing small counting area (frame) with step area (X, Y step). Accordingly, F2 was calculated as $40 \times 40 \mu \mathrm{m}^{2} / 220 \times 220 \mu \mathrm{m}^{2}=1 / 12=0.033$. Finally, cerebellum Purkinje cell layer was scanned within the range defined over $\mathrm{X}-\mathrm{Y}$ axis with systematic random sampling. For cross-section thickness and optic dissector height measurements, 'micro-screw calibration' method developed by Korkmaz and Tümkaya (1997) was used. In this way, thickness sampling fraction (F3) was calculated for each rat separately by dividing average dissector height (hort) with average cross-section thickness (tort) 


\section{Cerebellum Purkinje cell counts and calculations}

The method developed by Korkmaz et al. (2000) was used for Purkinje cell counts. For this method, Purkinje profile of each preparate was imaged with $10 \mathrm{X}$ objective, then acetate template including X, Y steps (large squares) and unbiased counting frames (small squares) were placed over the monitor (Fig 1 and 2). In this magnification, in systematic randomly sampled every seventh area, cross-section thickness (t) was determined with $100 \mathrm{X}$ objective (numerical aperture 1.25). In these areas, upper surface of the cross-section was focused and the location of pointer over the scale was determined. Then the lower surface of the cross-section was focused and the unit movement of the pointer with respect to initial position was recorded. The distance covered by a unit of scale connected to micro-screw along Z-axis (1-degree movement of micro-screw) corresponded to $0.27 \mu \mathrm{m}$. Cross-sections were scanned in steps and with optic dissector, optically 11 units $(2.7 \mu \mathrm{m}$, $0.27 \times 11=3 \mu \mathrm{m}$ ) were moved downward from the upper surface of the cross-section at Purkinje cell count phase. Cross-section scanning was performed at this level. The parameters obtained in this study were placed in equation of $\mathrm{N}($ Total $)=\left(\sum \mathrm{Q}-\right) \times(1 /$ F1) x (1/ F2) x (1/F3) (West et al., 1991). In this way, average number of cerebellum Purkinje cells of each group was calculated.

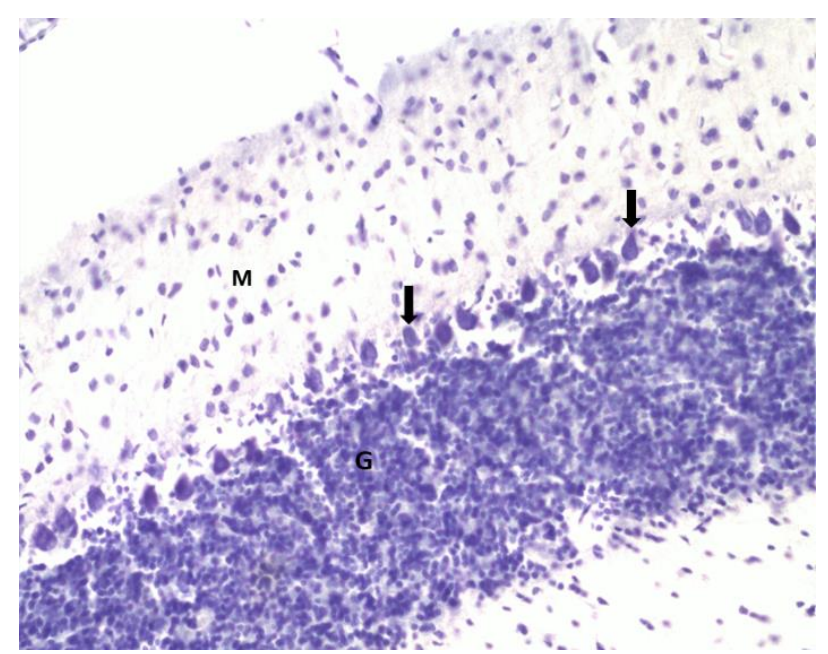

Figure 1. Photomicrograph of cerebellum from control group. G: Granular layer, M: Molecular layer, Purkinje cells (arrows), cresyl violet, 20x

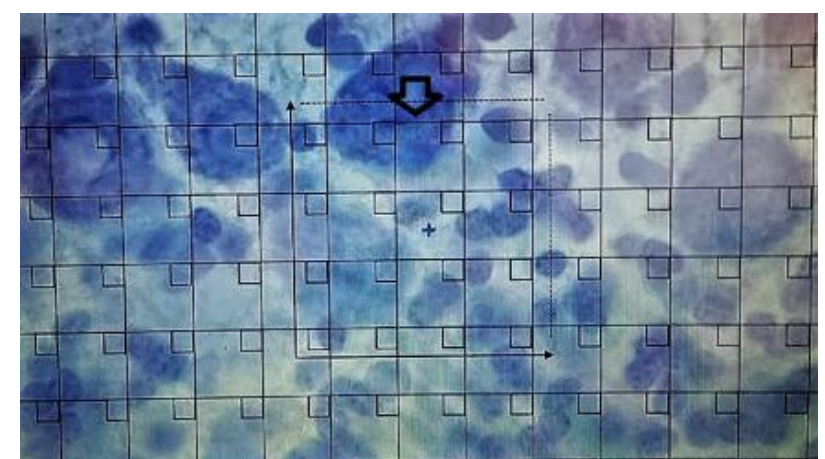

Figure 2. Systematic random sampling area fraction on the sampled section. X, Y steps (large squares) and unbiased counting frames (small squares), Dissector granule (arrow), cresyl violet, 100x.

\section{Data Analysis}

Statistical analyses were performed with SPSS (Statistical Package for Social Sciences for Windows) Version 20. One-Way ANOVA was used to compare treatment groups. Differences between the groups means was assessed with post hoc Tukey test.

\section{Results}

Average number of Purkinje cells present in cerebellum of rats is provided in Table 1. Coefficient of variation was calculated for each group (a value to be less than 0.10 ) to prove accuracy of the study. As compared to the control group (C), 34.6\% cellular loss was observed in $\mathrm{Al}_{2}\left(\mathrm{SO}_{4}\right)_{3}$ group and $27.9 \%$ lose was observed in $\mathrm{S}$ group. $\mathrm{In} \mathrm{Al}_{2}\left(\mathrm{SO}_{4}\right)_{3}$ +AG group, amino-guanidine reduced cellular loss by $22.3 \%$ as compared to $\mathrm{C}$ group and by $14.3 \%$ as compared to $\mathrm{S}$ group (Table 1). The differences in Purkinje cell counts of $\mathrm{C}$ and $\mathrm{S}$ groups and the differences in Purkinje cell counts of $\mathrm{Al}_{2}\left(\mathrm{SO}_{4}\right)_{3}$ groups were found to be significant $(p<0.01)$. 
Table 1. Average number of Purkinje cells in cerebellum, standard error of the mean (SEM) and coefficients of variance $(\mathrm{CV})$.

\begin{tabular}{llc}
\hline Groups & $\begin{array}{l}\text { Average number of } \\
\text { Purkinje cells } \pm \\
\text { SEM }\end{array}$ & $\begin{array}{c}\text { Coefficient } \\
\text { variation } \\
(\mathbf{C V})\end{array}$ \\
\hline $\mathbf{C}$ & $417615 \pm 16238,8$ & 0,06 \\
$\mathbf{S}$ & $378650 \pm 20171,6$ & 0,06 \\
$\mathbf{A l} \mathbf{S}_{\mathbf{S O}} \mathbf{S O}_{3}$ & $272945 \pm 15499,5$ & 0,06 \\
$\mathbf{A l}_{\mathbf{2}}\left(\mathbf{S O}_{4}\right)_{3}+\mathbf{A G}$ & $324581 \pm 16324,8$ & 0,08 \\
\hline
\end{tabular}

Post hoc Tukey test revealed that differences in Purkinje cell counts of the experimental groups were significant $(\mathrm{p}<0.01)$. One-Way ANOVA test revealed that $\mathrm{Al}_{2}\left(\mathrm{SO}_{4}\right)_{3}$ group was significantly different from $\mathrm{C}$ and $\mathrm{S}$ groups $(\mathrm{p}<0.01)$. There were significant differences also between $\mathrm{Al}_{2}\left(\mathrm{SO}_{4}\right)_{3}$ group and $\mathrm{Al}_{2}\left(\mathrm{SO}_{4}\right)_{3}+\mathrm{AG}$ group $(\mathrm{p}<0.01)($ Fig 3$)$.

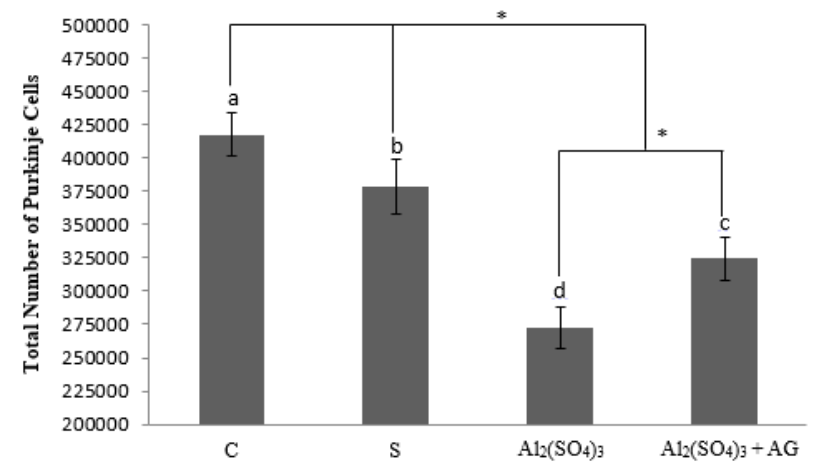

Figure 3. Cerebellum Purkinje cell counts for $\mathrm{C}, \mathrm{S}$, Al2(SO4)3 and Al2(SO4)3 + AG groups. a, b, c, d express different groups of post hoc Tukey test. * $\mathrm{p}<0.01$ significance level used to compare the groups with oneway ANOVA.

\section{Discussion}

Accumulation and damages of different $\mathrm{Al}$ forms on target organ and in body tissues were reported in previous studies (Kutlubay et al., 2007a; Oğuz et al., 2008, 2012). Exposure to high Al levels results in neural degeneration characterized by programmed and selective neuron loss (Stevanović et al., 2010). Al has neurotoxic impacts through inhibiting DNA repair enzymes (Bharathi et al., 2008), destroying cell membrane integrity (Zatta et al., 2002; Stevanović et al., 2010), increasing production of reactive oxygen species (ROS) (Ogasawara et al., 2003) and reducing neurotransmitter biosynthesis (Cheng et al., 2014).

$\mathrm{Al}$ is a source of oxidative stress and results in lipid peroxidation through the abundance of polyunsaturated fatty acids in cerebellum (Chaudhary et al., 2014). Al actualizes such impacts through increasing cerebral NOS levels (Bondy et al., 1998). In such cases, reduced forms of excessively produced NO increases. Excessive reduced NO reacts with superoxide (O2-) and thus increases proxy nitrite (ONOO-) and free radical formation. Increased free radicals eject electrons from cell membrane lipids and results in lipid peroxidation. Lipid peroxidation then accelerates cell deaths (Marangoz, 1996). Sharma et al. (2007) treated rats orally with $172.5 \mathrm{mg} / \mathrm{kg}$-day aluminium chloride for 10 weeks and reported significant decreases in SOD, GSPx and CAT antioxidant enzyme levels and significant increases in lipid peroxidation levels. Similar results were also reported in another study carried out with aluminium lactate-treated rats (Ogasawara et al., 2003). There are evidences that $\mathrm{Al}$ induced apoptosis-mediated neural deaths. Çabuş et al. (2014) carried out a study on rats treated with aluminium sulphate $(3 \mathrm{mg} / \mathrm{kg}$ i.p.) and assessed the neurons in stratum pyramidale layer of left-hemisphere with TUNEL method and reported significant decreases in number of neurons of aluminium-treated rats, then indicated aluminium as a neurotoxic agent and also indicated that neural death mechanisms might have been resulted from apoptosis. It was also showed that $\mathrm{Al}$ might result in cell damages in different tissues like thyroid follicles. It was reported in a previous study that $5 \%$ aluminium chloride supplementation of drinking water created significant damages on thyroid follicles of rats $(\mathrm{p}<0.05)$ (Aktaç and Bakar, 2002). Malekshah et al. (2005) reported that aluminium chloride treatments $(150 \mathrm{mg} / \mathrm{kg}$, i.p.) for 10,11 and 12 days created anomalies in fetus and reduced body weight of pregnant rats. Al may also reduce DNA and RNA synthesis and thus inhibit protein synthesis (Darbre, 2006). Buraimoh et al. (2014) in a study investigating the effects of $\mathrm{Al}$ on Purkinje cells, treated rats with aluminium chloride $(40 \mathrm{mg} / \mathrm{kg})$ for 4 weeks and reported significant decreases in Purkinje cell counts of treated rats through neurodegeneration as compared to untreated control rats.

In present stereological study with systematic random sampling, there was $34.6 \%$ decrease in number of Purkinje cells in cerebellum of $\mathrm{Al}$ (3 $\mathrm{mg} / \mathrm{kg}$, i.c.v.) treated group as compared to control group. Such a case revealed that $\mathrm{Al}$ had neuro-toxic impacts on Purkinje cells and the case may be attributed to increased NOS production (Esparza et al., 2005; Kozan et al, 2009; Buraimoh et al., 2014). It was reported in previous studies that toxic impacts 
of aluminium may reduce antioxidants like vitamin E (Kutlubay et al., 2007b), AG (Stevanović et al., 2010), taurine (Kozan et al., 2009). The AG used in this study to reduce the toxic impacts of $\mathrm{Al}$ was proved to reduce neurotoxic impacts resulted from increased aluminium sulphate-induced NOS levels (Önger et al., 2011). Sefil et al. (2009) reported that AG reduced iron-induced Purkinje cell loss from $25 \%$ to $12 \%$. It was reported in another study carried out on Wistar albino rats that $\mathrm{AlCl} 3$ treatments increased NO production in CA1 region of hippocampus 3 hours after the treatments, subsequently initiated neuro degeneration process, but combined $\mathrm{AlCl} 3+\mathrm{AG}$ treatments rapidly reduced NO production 3 hours after treatments (Stevanović et al., 2010). In another study carried out with AG, neuron damage resulted from excessive iNOS induced NO production was eliminated with AG $(100 \mathrm{mg} / \mathrm{kg}$, i.p., day) treatments ( $\mathrm{Lu}$ et al., 2002).

It was observed in present study, investigating the preventive effects of AG against cerebellar Purkinje cell loss, that $\mathrm{Al} 2(\mathrm{SO} 4) 3+\mathrm{AG}$ treatments reduced Purkinje cell loss by $22.3 \%$ and such a reduction revealed the preventive effects of AG against neuron damage. These findings support the earlier findings of researchers indicating AG as a specific iNOS inhibitor and may have preventive effects against neurotoxicity (Eroğlu et al., 2008; Gökçe et al., 2011). Neuron preventive effects of AG are realized through inhibiting the formation reactive oxygen radicals (ROR), inhibiting lipid peroxidation (LPO) in cell and tissues, scavenging hydrogen peroxide derivative hydroxyl radicals and prevention from oxidant-induced apoptosis (Özgüneş and Atasayar, 2009).

\section{Conclusion}

It was concluded based on present findings that AG, also known as an iNOS inhibitor, had preventive effects against neuron damage in cerebellum Purkinje cells resulted from Al-induced increased NOS levels. Nowadays, the use of Al in many areas especially on a sectoral basis causes people to be directly or indirectly exposed to toxic effects of Al. Therefore, the present study shows that amino-guanidine can be used to reduce the toxic effects of $\mathrm{Al}$, and it contributes to the literature in this issue.
Ethics Committee Approval: All experiments were conducted in accordance with the guidelines for care and use of laboratory animals and protocols were approved by the local ethical committee on experimental animals (2014/14), Ondokuz Mayıs University, Samsun, Turkey.

Peer-review: Externally peer-reviewed.

Author Contributions: Concept HG; Design BB; Supervision HG, BDY; Materials HG, BB; Data collection and/or Processing BB; Analysis and/or Interpretation BB, BDY; Literature Review BE, BDY, BB; Writing BDY; Critical Review BE, BDY. Conflict of Interest: No conflict of interest was declared by the authors.

Financial Disclosure: Funding was provided by Ondokuz Mayıs University Research Grant PYO.FEN.1904.14.012.

\section{References}

Aktaç T, Bakar E. The histopathological changes in the mouse thyroid depending on the aluminium. Journal of Cell and Molecular Biology 2002; 1: 69-72.

Anaeigoudari A, Soukhtanloo M, Reisi P, Beheshti $\mathrm{F}$, Hosseini M. Inducible nitric oxide inhibitor aminoguanidine, ameliorates deleterious effects of lipopolysaccharide on memory and long term potentiation in rat. Life Sciences 2016; 158: 2230.

Babu E, Gopalakrishnan VK, Sriganth IN, Gopalakrishnan R, Sakthisekaran D. Cisplatin induced nephrotoxicity and the modulating effect of glutathione ester. Mol Cell Biochem 1995; 144:7-11.

Bharathi, Vasudevaraju P, Govindaraju M, Palanisamy AP, Sambamurti K, Rao KSJ. Molecular Toxicity of Aluminium in Relation to Neurodegeneration. Indian J Med Res 2008; 128:545-556.

Bondy SC, Liu D, Guo-Ross S. Aluminum treatment induces nitric oxide synthase in the rat brain. Neurochem Int 1998; 33: 51-54.

Budavari S, O'Neil MJ, Smith A, Heckelman PE. 8th edition. In: Stecher PG. The Merck Index. 1989.

Buraimoh AA, Tayo I, Ojo SA. Effects of Aluminium Chloride on the Histology of Cerebellum of Wistar Rats. Pharmacology\&Toxicology Research 2014; 1:14. 
Çabuş N, Oğuz EO, Tufan AÇ, Adigüzel E. A histological study of toxic effects of aluminium sulfate on rat hippocampus. Biotechnic \& Histochemistry 2014; 90-2.

Çabuş N. The Effect of Aluminium Sulphate on rat Hippocampal Cell Populations at Toxic Dose. Denizli: Pamukkale University Health Sciences Institute, 2012.

Chaudhary M, Joshi DK, Tripathi S, Kulshrestha S, Mahdi AA. Docosahexaenoic acid ameliorates aluminum induced biochemical and morphological alteration in rat cerebellum. Annals of Neurosciences 2014; 21:1.

Cheng D, Xi Y, Cao J, Dongdong C, Ma Y, Jiang W. Protective effect of apple (Ralls) polyphenol extract against aluminum-induced cognitive impairment and oxidative damage in rat. NeuroToxicology 2014; 45: 111-120.

Darbre PD. Metalloestrogens: an emerging class of inorganic xenoestrogens with potential to add to the oestrogenic burden of human breast. Journal of Applied Toxicology 2006; 26: 191-197.

Eroglu C, Yıldız OG, Saraymen R, Soyuer S, Kılıç $\mathrm{S}$, Özcan S. Aminoguanidine ameliorates radiation-induced oxidative lung damage in rats. Clin Invest Med 2008; 31 (4).

Esparza JL, Go'mez M, Nogue's MR, Paternain JL, Mallo J, Domingo JL. 2005. Melatonin reduces oxidative stress and increases gene expression in the cerebral cortex and cerebellum of aluminumexposed rats. J Pineal Res 2005; 39:129-136.

Eweka AO, Om'Iniabohs FAE. Histological studies of the effect of the monosodium glutamate on the cerebellum of adult wistar rats. The Internet journal of Neurology 2007; 8: 1-4.

Flora SJS, Mehta A, Satsangi K, Kannan GM, Gupta M. Aluminum-induced oxidative stress in rat brain: response to combined administration of citric acid and HEDTA. Comparative Biochemistry and Physiology Part 2003; 134(3):319-328.

Gökçe MF, Kaplan S, Türkkanı A, Kozan R, Ayyıldız M, Emirzeoğlu M, Aslan H, Marangoz C. Nitric oxide synthase inhibitors protect cerebellar Purkinje cells from zinc-induced cell loss in adult rat. Journal of Chemical Neuroanatomy 2011; 41:25-31.

Gross SS, Volin MS. Nitric oxide: pathophysiological mechanisms. Annu Rev Physiol 1995; 57: 737-769.

Gundersen HJG, Jensen EB. The efficiency of systematic sampling in stereology and its prediction. J Microsc 1987; 147: 229-263.
Kamal I, Kamal H. Effects of aluminum on rat cerebellar cortex and the possible protective role of Nigella sativa: a light and electron microscopic study. Egypt J Histol 2013; 36:979-990.

Korkmaz A, Çiftçi N, Boşnak M, Ağar E. Simplified application of systematic field sampling and lowcost video recording set-up for viewing disector pairs-exemplified in the rat cochlear nucleu. Journal of Microscopy 2000; 200: 26-276.

Korkmaz A, Kaplan S, Çiftçi N, Bilgiç S, Rağbetli MÇ. A morphometric study of the inferior olivary nucleus in rats treated prenatally with diclofenac sodium. Turkish Journal of Medical Sciences 1996; 26:75-79.

Korkmaz A, Tümkaya L. Estimation of the section thickness and optical disector height with a simple calibration method. Journal of microscopy 1997; 187:104-109.

Kozan R, Bostancı MO, Ayas B, Aslan A, Bağırıcı F. Protective Effect of Vitamin E against Iron induced Neurotoxicity in the Rat Cerebellum. Firat Tip Dergisi 2009; 14(1):07-1.

Kutlubay R, Oğuz EO, Can B. Vitamin E protection from testicular damage caused by intraperitoneal aluminium. Int J Toxicol 2007 b; 26:297-306.

Kutlubay R, Oğuz EO, Güven C. Histological and ultrastructural evidence for protective effects on aluminium-Induced kidney damage by intraperitoneal administration of alpha tocopherol. Int J Toxicol 2007a; 26:95-101.

Lu J, Moochhala S, Shirhan M, Chye K, Teo AL, Tan MH, Moore XL, Wong MC, Ling EA. Neuroprotection by aminoguanidine after lateral fluid-percussive brain injury in rats: a combined magnetic resonance imaging, histopathologic and functional study. Neuropharmacology 2002; 44: 253-263.

Malekshah AK, Torabizadeh Z, Naghshwar F. Developmental Toxicity of Aluminum from High Doses of $\mathrm{AlCl} 3$ in Mice. The Journal of Applied Research 2005; 5 (4): 575-579.

Marangoz C. Nitric Oxide and Experimental Epilepsy. Ondokuz Mayıs Universty Medical Journal 1996; 13 (3): 165-183.

Ogasawara Y, Ohata E, Sakamoto T, Ishii K, Takahashi H, Tanabe SA. A Model of aluminium exposure associated with lipid peroxidation in rat brain. Biol Trace Elem Res. Biol Trace Elem Res 2003; 96(1-3): 191-201.

Oğuz EO, Enli Y, Şahin B, Gönen C, Turgut G. Aluminium sulphate exposure increases oxidative stress and suppresses brain development in Ross broiler chicks. Med Sci Monit 2012; 18(3): 103-108. 
Oğuz EO, Yuksel H, Enli H, Enli Y, Zorbozan O, Can Z, Turgut G. Oxidative and Inflamatory Damage of Aluminium Suplhate on the Liver of Term Ross Broiler Chick. Ankara University Medical Journal 2008; 61(1).

Önger ME, Genç H, Tan F. Effect of NOS inhibitors applied with cadmium sulphate on total lipid and protein quantities in central nervous system of rat (Wistar albino). J Exp Clin Med 2011; 28: 175.

Özgüneş H, Atasayar S. Aminoguanidine and the its significance in diseases. Turkiye Klinikleri J Med Sci 2009; 29 (4): 976-86.

Polat A, Parlakpinar H, Tasdemir S, Colak C, Vardi $\mathrm{N}$, Ucar M. Protective role of aminoguanidine on gentamicin-induced acute renal failure in rats. Acta histochemica 2006; 108:365-71.

Satarug S, Baker JR, Reilly PEB, Esumi H, Moore MR. Evidence for a Synergistic Interaction between Cadmium and Endotoxin Toxicity and for Nitric Oxide and Cadmium Displacement of Metals in the Kidney. Nitric Oxide: Biology and Chemistry 2000; 44: 431-440.

Sefil F, Kozan R, Bostancı MÖ, Bağırıc1 F. Protective effect of inhibition of nitric oxide synthase on iron-induced purkinje cell loss. Tip Araştırmaları Dergisi 2009; 7(2): 71-78.

Sharma P, Ahmad Shah Z, Kumar A, Islam F, Mishra KP. Role of combined administration of Tiron and glutathione against aluminum-induced oxidative stress in rat brain. J Trace Elem Med Biol 2007; 21(1): 63-70.

Stevanović ID, Jovanović MD, Jelenković A, Colić M, Stojanović I, Ninković M. The Effect of Aminoguanidine, an Inducible Nitric Oxide Synthase Inhibitör, On AlCl3 Toxicity in the Rat Hippocampus. Arch. Biol Sci 2010; 62 (4): 981991.

Tunç AT, Aslan H, Turgut M, Ekici F, Odacı E, Kaplan S. Inhibitory effect of pinealectomy on the development of cerebellar granule cells in the chick: A stereological study 2007; 1138: 214220.

Türköz Y, Özerol E. Nitric oxide: actions and pathological roles. Journal of Turgut Özal Medical Center 1997; 4(4): 453-461.
West MJ, Slomianka L, Gundersen HJ. Unbiased stereological estimation of the total number of neurons in the subdivisions of the rat hippocampus using the optical fractionator, Anat Rec 1991; 231: 482-497.

Yavuz CI, Vaizoğlu AS, Güler Ç. Aluminium in Drinking Water. TAF Prev Med Bull 2013; 12(5): 589-596.

Yokel AR, Hicks LC, Florence LR. Aluminum Bioavailability from Basic Sodium Aluminum Phosphate, an Approved Food Additive Emulsifying Agent, Incorporated in Cheese. Food Chem Toxicol 2008; 46(6): 2261-6.

Zatta P, Ibn-Lkayat-Idrissi M, Zambenedetti P, Kilyen M, T. Ki ss (2002): In vivo and in vitro effects of aluminum on the activity of mouse brain acetylcholinestrase. Brain Res 2002; 59: 41-45. 